CORDÃO, Francisco Aparecido; MORAES, Francisco de. Educação profissional no Brasil: síntese histórica e perspectivas. São Paulo: Ed. Senac São Paulo, 2017.

\title{
A educação profissional a partir da experiência de seus educadores
}

É provável que aqueles que já tiveram a oportunidade de ouvir o professor Cordão falar da educação profissional tenham ficado com a feliz impressão de que ele, além de conhecê-la profundamente, tem por ela um enorme apreço. Tanto esse conhecimento quanto essa estima aparecem na sua obra (aqui nos referimos, em específico, ao livro objeto desta resenha e, de forma geral, à atuação do professor Cordão na área). Trabalhador da educação profissional há mais de 40 anos, Francisco Aparecido Cordão constrói, em parceria com Francisco de Moraes (também trabalhador da área), uma crítica da educação profissional brasileira com base em sua história, partindo de um relato sobre as nações indígenas, os "verdadeiros brasileiros originais", segundo os autores.

Este é, inclusive, um dos pontos fortes da obra: a discussão sobre a formação para o trabalho que os índios empreendiam antes da chegada dos portugueses. A educação tinha, para esses povos, íntima relação com a vida cotidiana e com a socialização das pessoas; a formação para o trabalho pouco se distinguia da educação familiar, para o lazer e para a religião. Era um processo conjunto e unívoco, segundo os autores. Além disso, nesse capítulo é abordada a forte preocupação dos índios com a estética, o cultivo do belo e a qualidade dos artefatos produzidos. Aparentemente, o conceito de competência proposto no livro foi influenciado por essa herança dos índios, pois reforça a importância do fazer bem-feito, do cultivo à beleza da obra acabada.

Quando tratam da formação de professores, outro destaque do livro, os autores também indicam a relevância da obra em aprendizagens do saber do trabalho. Reforçam a necessidade de eles serem capazes de produzir as obras nas quais os alunos serão envolvidos. As contribuições inéditas que o livro traz para a formação 
docente representam uma das bases para garantir a sustentabilidade e a capilaridade da educação profissional brasileira. Os autores são otimistas quanto ao futuro da educação profissional no País, devido a uma recente valorização observada por meio de programas oficiais, como Programa Nacional de Integração da Educação Profissional com a Educação Básica na Modalidade de Educação de Jovens e Adultos (Proeja), Programa Nacional de Acesso ao Ensino Técnico e Emprego (Pronatec), Rede e-Tec, Brasil Profissionalizado e outros. Todavia, essa perspectiva só pode ser consolidada a partir de uma formação docente sintonizada com essa demanda, projetos pedagógicos vinculados ao trabalho e infraestrutura de laboratórios, oficinas e demais ambientes para o desenvolvimento das competências inerentes à formação técnica. Conclui-se, a partir da leitura do capítulo Formação Docente, que os professores da educação profissional precisam de uma formação específica, baseada na epistemologia da técnica, na didática profissional e nos saberes do trabalho.

\section{0 trabalho: fundamento e inspiração para a educação profissional}

Esse movimento em direção à valorização do trabalho é outro ponto forte da obra, além de ser urgente para o País. Cordão e Moraes (2017, p. 183) afirmam que "não se reconhece facilmente que o trabalho é pleno de saberes da maior importância". A análise histórica elaborada pelos autores mostra que esse "desvalor" do trabalho tem origem, em grande parte, na nossa herança colonial escravista e preconceituosa. Em educação profissional, contudo, o trabalho precisa ter centralidade como princípio educativo, afinal, ela é formação para o trabalho. Os autores destacam a importância da educação profissional como caminho para o atendimento a dois direitos fundamentais do cidadão: o direito à educação e o direito ao trabalho. Nesse sentido, enfatizam que as instituições de educação profissional têm como principal objetivo e como compromisso ético preparar as pessoas para a vida produtiva, por meio do desenvolvimento das competências profissionais necessárias ao exercício de uma ocupação, em condições de alterá-la com perspicácia.

Para alcançar esse objetivo e cumprir seu compromisso, as instituições devem, segundo os autores, buscar na realidade do trabalho as informações para construírem os itinerários formativos. A base para definir os perfis de conclusão dos cursos deve ser a realidade da ocupação e os caminhos práticos percorridos no país, na região e no local de oferta. Aqui temos outra valiosa contribuição desta obra para a educação profissional brasileira: a afırmação da necessidade de aproximação da escola com o mundo do trabalho. Já em seu primeiro artigo, a LDB diz que "a educação escolar deverá vincular-se ao mundo do trabalho e à prática social." Cordão e Moraes conferem a um dos capítulos do livro o título "Após a educação básica tudo é educação profissional", questionando a desvinculação da educação superior com o trabalho. Contudo, pode-se dizer, conforme a própria Lei de Diretrizes e Bases da Educação Nacional (LDB), que toda a educação escolar, básica e superior, deve estreitar laços com o mundo do trabalho, ou seja, deve ser também, em alguma medida, profissional. 


\section{Convite para (re)leituras}

Outros trechos do livro nos lembram da importância de retomar pensadores para melhor entendermos a educação profissional. Com razão, os autores ressaltam a relevância da obra de Álvaro Vieira Pinto. Aqui pensamos que a obra deste fantástico filósofo brasileiro mereceria um aprofundamento e uma retomada, o que talvez permitisse evitar algumas armadilhas, como a de uma certa hierarquização das formações e profissões, ignorando o valor e papel próprios de cada uma, ou a de uma suposta sofisticação das competências mais bem fundamentadas cientificamente. Neste último caso, é provável que Álvaro Vieira Pinto não concordasse com uma epistemologia que considerasse a tecnologia apenas segundo o senso comum, ou seja, como "aplicação" da ciência ou como conjunto de objetos ou produtos tecnológicos. Afınal, esse grande filósofo brasileiro nos trouxe preciosos ensinamentos: o quão fundamental é a técnica para o ser humano (ela é, nos lembra Moraes - outro Moraes - a mãe da ciência, e não filha desta). Mas justamente devido a esta função vital da técnica, precisamos consolidar uma ciência que dê conta de explicá-la, caracterizá-la, desenvolvê-la: a Tecnologia! Em outras palavras, esta deixa de ser vista como decorrência de um pensamento científico e faz-Ihe ganhar outra dimensão: a de um campo de práticas e de saberes que busca diversas fontes, como a científica, mas que tem sua função e originalidade próprias. Do mesmo modo, a formação técnica não pode mais ser pensada e organizada como se uma base sólida de conhecimentos científicos pudesse gerar uma boa formação técnica. Grande parte dos saberes e dos fazeres próprios de uma profissão ou de uma área técnica simplesmente não são produzidos no campo da ciência ou das academias. Esta é mais uma virtude do livro: o convite à leitura de autores que merecem muito mais citações!

Para concluir esta resenha, retomamos os objetivos do livro: apresentar e discutir a história da educação profissional brasileira, apontando as perspectivas. Como síntese histórica, o livro de Cordão e Moraes cumpre muito bem seu objetivo. Apresenta, inclusive, uma rica linha do tempo, com esclarecedores relatos de marcos da história do Brasil e de sua educação profissional. E no capítulo "Escolas técnicas públicas: federais e estaduais", ainda detalha algumas datas de referência na história da Rede Federal de Educação Profissional, Científica e Tecnológica. Contudo, talvez o livro desempenhe um papel ainda mais importante quando trata das perspectivas, ao abordar a necessidade de superação das heranças malditas, o escravismo, o cartorialismo e o patrimonialismo, por meio de uma educação profissional baseada na valorização do trabalho e do reconhecimento de que "toda educação profissional é educação humana integral” (CORDÃO; MORAES, 2017, p. 183).

\section{Crislaine Gruber, Olivier Allain e Paulo Wollinger}

Professores no Instituto Federal de Santa Catarina, em Florianópolis, atuando na formação de docentes para a Educação Profissional.

crislaine.gruber@ifsc.edu.br

olivier@ifsc.edu.br

wollinger@ifsc.edu.br 
1 Jarbas Novelino Barato, no artigo "Conhecimento, trabalho e obra: uma proposta metodológica para a educação profissional", publicado no Boletim Técnico do Senac, v. 34, n. 3, set./dez. 2008, discute sobre o conceito de obra. Disponível em: <http://www.bts.senac.br/index.php/bts/article/view/262\%3E>. Acesso em: 19 mar. 2018.

${ }^{2}$ Mike Rose (2007), em outro livro da Editora Senac São Paulo, "O saber no trabalho: valorização da inteligência do trabalhador", desenvolve muito bem uma discussão sobre os saberes do trabalho.

${ }^{3}$ Gustavo Henrique Moraes, pesquisador do Instituto Nacional de Estudos e Pesquisas Educacionais Anísio Teixeira (Inep), autarquia federal vinculada ao Ministério da Educação (MEC), é autor da tese "Identidade de Escola Técnica vs. Vontade de Universidade: a formação da identidade dos Institutos Federais", defendida em 2016, na Universidade de Brasília. Disponível em: <http://repositorio.unb.br/ handle/10482/21409>. Acesso em: 19 mar. 2018. 